international co-operation recommended by the Conference in a series of resolutions are the standardization and intercalibration of methods and equipment - such as the sizes and types of nets and the techniques used in the collection of plankton; the collection and exchange of oceanographical data; and the organization of joint research programmes in specified regions by groups of countries, such as that planned for the Indian Ocean. The Conference also asked Governments and international organizations to take immediate steps to prevent pollution by radioactive material and to intensify their research programmes in this field.

\section{Cosmic Radiation Studies in South America}

THE Latin American Council of Cosmic Radiation, with members from Argentina, Bolivia, Brazil, Chile, Mexico, Peru, Puerto Rico and Venozuela, met during August $1-3$ at the Centro Brasileiro de Pesquisas Físicas in Rio de Janeiro. Observers representing the International Union of Pure and Applied Physics and Unesco were also present. The mocting was called and organized by Unesco's Centre of Scientific Co-operation for Latin America, Montevideo. The Council decided to organize a brief course of three weeks duration and seminars to be held in Mexico beginning late in June 1961. The latter will cover the following topies: composition of primary cosmic radiation, physies of interplanetary plasma, solar physics, time variations, extensive air showers and theory of goomagnetic effects. An effort will be made to secure the participation of physicists from other than Latin American countries in these seminars. The Council hopes to send through proper channels suggestions for experiments which can be made aboard space vehicles and artificial satellites. Members of the Council attending the Rio meeting were Prof. José Manzano (Argentina), Dr. Narayan Nerurkar (Bolivia), Prof. Georges Schwachheim (Brazil), Prof. Gabriel Alvial (Chile), Prof. Manuel S. Vallarta (Mexico) and Prof. Manuel Bemporad (Venezuela). Observers present were Prof. (Gabriel Fialho (International Union of Pure and Applied Physics), Dr. Angel Establier (Unesco), Prof. Gleb Wataghin (University of Turin) and Prof. Gianpietro Puppi (University of Bologna). Prof. Vallarta acted as chairman.

\section{Fossil Meteorites}

AdDitional information is providod by B. I. Vronsky (Priroda, 9, 116; 1959) on the probable 'fossil meteorite' (Nature, 184, 1026; 1959). This moteorite was discovered in November 1957 in the valley of a small river, Zarya, a tributary of the Susuman River, itself a tributary, Berelekh, Magadan district of Siberia. This meteorite, which received the name 'Susuman' and which weighed about $19 \mathrm{kgm}$., was discovered at the base of an alluvial doposit consisting of gravels and mud. Thus, in age it is assumed to be Post-Glacial and about 15-20 thousand years old. It is only now that it has been made known that in this region, a few years previously, two similar meteorites have been discovered in similar situations. Thus, the iron meteorite, 'Mal'dyak', was discovered at a depth of $4.6 \mathrm{~m}$. in gravels of the River Mal'dyak situated $28 \mathrm{~km}$. to the south of Susuman. In 1941 the iron meteorito 'Burgavli', weighing $24.9 \mathrm{kgm}$., was found in the gravels of the Rivor Adachi, a right tributary of Yana River. These three meteorites are now being studied in detail.

\section{Industrial Health in Britain}

Mr. R. CARr asked in the House of Commons for a statement about the development of industrial health services in Britain. The Minister of Labour, Mr. E. Heath, said in reply on July 25 that the development of such services is under consideration by tho Industrial Health Advisory Committec. Legal requirements safeguarding the health of industrial workers are contained in the Factories Acts and Regulations, which are constantly being revised and extended. In addition, many firms voluntarily provide medical and nursing services, and to encourage more employers to do so, a booklet is to be published later this year giving details of the cost of some of these services, together with the views of management and work-people about thom. Group schemes have also operated successfully in a few places with special circumstances, such as Slough and Harlow, and we now noed to explore the possibilities of establishing group schemes in areas of a different kind. Another need is the further use and development of industrial hygienic services to carry out chomical, physical and biological tests where special hazards exist or are suspected. The Minister said that arrangements are being made to sot up an organization to collect information about existing facilities regularly and to make it available to employers. $\mathrm{He}$ had discussed further action with the Nuffield Foundation, which has had considerable experience in promoting industrial health schemes, and the Trustees of the Foundation are allocating $£ 250,000$ for the further development of group indus. trial health schemes and industrial hygienic schemes. The money will be used to assist practical schemes which promise to become self-supporting, and in selecting such schemes the Foundation would work in the closest co-operation with the Ministry of Health.

\section{Preparing Teachers for Health Education}

Health education is not always recognized as a discipline of its own and given its appropriate place in the training of teachers. A report of a joint World Health Organization/Unesco Expert Committee (World Health Organization: 'Technical Report Sories. No. 193. 1960. 1s. 9d.) provides a flexible framework of guiding principles for such training, which should take place not only through courses of instruction but also through the teacher's actual mode of life in his training institution, his contact with student health services, and his experiences when practising teaching. Health education in schools should be based on the health needs and interests of the children, the toacher having opportunities for imparting it, both directly and by the part he can play in the school health services and in planning a hoalthy school. To enablo him to make the most of his opportunities he must have some knowledge of growth and development, personal and community health, health practice in schools, and methods of health education. The report discusses these subjects, the future teacher's life as a student in relation to his opportunitios for hoalth work and to health services for students, practice teaching and the education he acquires as a fully-fledged toacher. Other sections deal with planning of training for teachers in health education, the desirability of one person in each training institution being responsible for co-ordination of courses and activities in health education, and possible future national and international developments, studies and research in the subject. 